\title{
THE USE OF FIGURATIVE LANGUAGES ON THE STUDENTS' POETRY SEMESTER V AT FKIP UNIVERSITAS HKBP NOMMENSEN
}

\author{
Bertaria Sohnata Hutauruk* \\ University of HKBP Nommesen \\ Received on 12 April 2019 / Approved 24 April 2019
}

\begin{abstract}
This research discusses The Use of Figurative Languages on the Students' Poetry Semester V at FKIP Universitas HKBP Nommensen. The problems of this research are (1) what types of figurative language used on the students' poetry semester V at FKIP Universitas HKBP Nommensen Medan? (2) what figurative language is dominantly used on the students' poetry semester V at FKIP Universitas HKBP Nommensen Medan? The objectives of this research are to find out types of figurative language used on the students' poetry semester $\mathrm{V}$ at FKIP Universitas HKBP Nommensen Medan and to figure out and analyze what figurative language is dominantly used on the students' poetry semester V at FKIP Universitas HKBP Nommensen Medan? To find out the answer of the problem in this research, the writer uses the related theories; they are Quinn (1982), McDonough and Shaw (1993), Gluckberg (2001), Alm-Arvius (2003), Lazar (2003), Ratumanan and Laurens (2003), Brown (2004), Harmer (2004), Heller (2006), Picken (2007), Keraf (2009), Creswell (2009), Arikunto (2010), Arnold and Von Hollander (2011), Dalman (2012), Dancygier and Sweetser (2014). This research is conducted with descriptive qualitative research where the subject and object is taken from the students' poetry. The writer gets the data by observation and documenting. After the data had been collected, the writer finds out three types of figurative language on the students' poetry: symbol, metaphors and personifications. In teaching poetry, every teacher needs to call upon a number of techniques and methods. If teachers of poetry disagree on the methods of teaching a certain poet, they must agree on goals: To put their students in touch with the mind of that poet. No doubt, it is known for every one that good poetry lessons occur in classrooms where young people are guided by responsive teachers who implement as well as they plan.
\end{abstract}

Keywords: Figurative language, poetry, language

\begin{abstract}
ABSTRAK
Penelitian ini membahas penggunaan gaya kiasan pada puisi mahasiswa semester $V$ di FKIP Universitas HKBP Nommensen. Permasalahan dalam penelitian ini adalah (1) Apa jenis bahasa kiasan yang digunakan pada puisi siswa semester V di FKIP Universitas HKBP Nommensen Medan? (2) Bahasa kiasan apa yang dominan digunakan pada puisi siswa semester V di FKIP Universitas HKBP Nommensen Medan? Tujuan dari penelitian ini adalah untuk mengetahui jenis bahasa kiasan yang digunakan pada puisi mahasiswa semester $V$ di FKIP Universitas HKBP Nommensen Medan dan untuk mencari tahu dan menganalisis apa bahasa kiasan yang dominan digunakan pada puisi siswa semester $V$ di FKIP Universitas HKBP Nommensen Medan. Untuk mendapatkan jawaban atas masalah dalam penelitian ini, penulis menggunakan teori-teori terkait; Quinn (1982), McDonough dan Shaw (1993), Gluckberg (2001), Alm-Arvius (2003), Lazar (2003), Ratumanan dan Laurens (2003), Brown (2004), Harmer (2004), Heller (2006), Picken (2007), Keraf (2009), Creswell (2009), Arikunto (2010), Arnold dan Von Hollander (2011), Dalman (2012), Dancygier dan Sweetser (2014). Penelitian ini dilakukan dengan penelitian deskriptif kualitatif di mana subjek dan objek diambil dari puisi siswa. Penulis mendapatkan data dengan observasi dan dokumentasi. Setelah data dikumpulkan, penulis menemukan tiga jenis bahasa kiasan pada puisi siswa: simbol, metafora dan personifikasi. Dalam mengajar puisi, setiap guru perlu memanggil sejumlah teknik dan metode. Jika pengajar untuk mata kuliah puisi tidak setuju tentang metode mengajar penyair tertentu, mereka harus sepakat dengan tujuan untuk membuat mahasiswa mereka berhubungan dengan pikiran penyair itu. Setiap orang mengetahui bahwa pengajaran
\end{abstract}

*Author(s) Correspondence:

E-mail: rianahutauruk@yahoo.com 
penulisan puisi yang baik terjadi di ruang kelas dimana kaum muda dibimbing oleh pengajar yang responsif yang menerapkan dan merencanakan pembelajaran dengan baik.

Kata Kunci: bahasa kiasan, puisi, bahasa

\section{INTRODUCTION}

\subsection{Background}

Poetry, of all the other genres of literature is the oldest and the most critical genre. To make it more exciting, a teacher of literature in general and poetry in particular might depend on teaching the poetic texts that have personification and apostrophe as the most prominent figures of speech to create an optimal learning circumstance and to facilitate learning on behalf of the students and teaching on behalf of the teachers. Poetry is characterized by many characteristics, but the most significant is its language which is artificial and essentially different from the common everyday language that people speak. Although this may be true of some poetry, one can easily find numerous examples that demonstrate poetic diction of an entirely different sort. The poet is permitted with a special kind of liberty in using the language to convey his message; this liberty is called poetic license. This does not mean that there is a special vocabulary peculiar to poetry. The poet may go beyond the limits of the language by using this license to communicate new areas of experience. It gives the poet the chance to "twist or wrest the language according to his needs in the use of figurative speech, archaism, rhyme, strange syntax, etc" (Sayakhan, 2019, p. 51). Literary personification has long been taken for granted as the master trope of poetic language. A figure of speech, in poetry, "is not a mere decorative device, a pretty or fancy way of saying something which might be better said literally" (Deedari \& Mansouri, 2004, p. 12). Teachers should explain the figurative language with each types in the English literature class so the students. This is to make the students are successful in creating the poetry with the figurative language.

Based on the background above, the writer formulates the problems as follow: (1) what types of figurative language used on the students' poetry semester $\mathrm{V}$ at FKIP Universitas HKBP Nommensen Medan? (2) what figurative language is dominantly used on the students' poetry semester V at FKIP Universitas HKBP Nommensen Medan? It is important to make the scope and limitation of this research, in order to get more objectives data. Although there are some theories related with figurative language but the writer focuses on figurative language that used on the Astudents' poetry semester $\mathrm{V}$ at FKIP Universitas HKBP Nommensen Medan?

\section{REVIEW OF RELATED LITERATURE}

In order to define some terms used in this research, the writer formulates some theories related with the contents of the research. The theories that are used in this research will be useful to get relevant information in this chapter. The review of related literature is aim to give theoretical foundation on the paper. The theories that used in this chapter are: Wikipedia, the free encyclopedia, Quinn (1982), McDonough and Shaw (1993), Gluckberg (2001), Lazar (2003), Alm-Arvius (2003), Harmer (2004), Picken (2007), Stanley (2007), Keraf (2009), Arnold and Von Hollander (2011), and Dalman (2012).

\subsection{Figurative Language}

Figurative language uses words or expressions with a meaning that is different from the literal interpretation. Figurative language is produced in our daily conversation and often found in literary works, such as newspaper, advertisements, novels, poems, and so on.

\subsubsection{Definition of Figurative Language}

Figurative language is a language that is used imaginatively and not literary because

\footnotetext{
*Author(s) Correspondence:

E-mail: rianahutauruk@yahoo.com
} 
the use of the words diverging from its usual meaning. Figure of speech introduces an ambiguity between literal and figurative interpretation. Thus, when having to understand it people have to think deeply. The statement occurred when people are looking at figurative language obviously has an ambiguity meaning in it. In addition to that, Figurative language is not intended to be interpreted in a literal sense but it appeals on to the imagination. It is also supported by Gluckberg $(2001$, p. 4) that "a figure of speech in which a name or descriptive word or phrase is transferred to an object or action". Figurative language is language which uses figures of speech (a way of saying one thing and meeting another). In other words, it can't be taken literally (or should not be taken literally only) because it employs to heighten and improve an effect by introducing and comparing one certain thing to another more general thing but without figures of speech, the power of language to communicate would be crippled, like a dog without bark or bite.

Quinn (1982, p. 6) stated that "the simplest definition of a figure of speech is an intended deviation from ordinary usage". These figures of speech have been named and collected because they are used for properly, extremely helpful in learning and teaching how to write, speak, read, listen, better. The figures of speech also take a part to help people even students to see the words choices that are available in a given context which is able to give critic or judge value in its content. Picken $(2007$, p. 2) declared that "figurative language is noticed and frequently interpreted inconsiderable detail, and evaluation takes place."

\subsubsection{The Function of Figurative Language}

The function of figurative language is to stimulate a certain image. It affects the language beauty of work in both oral and written communication. On the other side, it is also related with understanding of Lazar (2003, p. 1) declared that "figurative language can provide a useful springboard for integrated skills work and to stimulate reading, speaking, and writing skills". It also includes activities which are designed to improve the students' overall language awareness and to encourage them to use English more confidently and imaginatively.

In other words, figurative language serves to convey thoughts, feelings, and perceptions that cannot be adequately expressed in literal language. It is declared also by Keraf (2009, p. 129) that figure of speech has function to explain, strengthen, a live, stimulate, decorate an object. It gave beneficial for the teachers and students for focusing on figurative language in the classroom which provide a way of exposing students to use it in leaning writing literary terms. Examples: The stars dancing happily in the sky; The cold night touch my deepest skin.

In the examples showed that figurative language used is "Personification" because the stars and cold night as if as human being who is able to do their activities such as touch and dancing in human's daily life.

\subsubsection{Kinds of Figurative Language}

In this research, the researcher discusses the figurative language based on Keraf's perception. Keraf (2009, p. 138) declared that "figurative language consists of 16 kinds, they are: Simile, Metaphor, allegory, Personification, Allusion, Eponym, Epithet, synecdoche, metonymy, Antonomasia, Hipflask or Hipalase, Irony, Satire, Innuendo, Antiphrasis, and Paronomasia.

\subsubsection{Simile}

Simile is a part of figurative language in English uses the conjunction such as as, like, resemble and so on to express the comparison two different things. Lazar (2003, p. 5) declared that "simile is an expression that describes something as being similar to something else, using words 'as or like". In other side, Keraf (2009, p. 138) declared that "simile is the comparison which has explicit nature". The explicit meaning is to say something directly which is same with other things. So, it needs the way explicitly that showed similarity, by the word or phrase such

\footnotetext{
*Author(s) Correspondence:

E-mail: rianahutauruk@yahoo.com
} 
as like, as, than, similar, resemble or seems. Simile is the simplest kind of figurative language to certain something. Here the example of simile from Lazar: My life is like empty room without your coming. The kind of figurative language is simile. It can be clearly and easily seen that the data uses simile as a kind of figurative language because the statement above use Like as a characteristic of simile. By using simile, the word like empty room is an utterance of somebody who declares his life becomes zero without his girlfriend.

\subsubsection{Metaphor}

Metaphor is a part of figurative language using an analogy or close comparison between two things that are not normally treated as if they had anything in common. Metaphor is common means of extending the uses and references of words. Alm-Arvius (2003, p. 90) declared that "metaphors are common in language use, and ordinarily it does not seem to require any particular effort to construct and understand them." Metaphor is a kind of figurative language to think something analogy. Here is the example of metaphor: You are the beautiful wealth sent by God to me. The example above can be said as a metaphor because it is constructed on the spot by the author to give an illustration of his feeling that his girlfriend is compared with beautiful wealth which is related to his imagination only. It is one which is understood only after paying special attention to the comparison between wealth in real context as noun and in its context is his girlfriend. There is comparison meaning between you and wealth. But in this context compare that You as human with wealth as noun.

\subsubsection{Allegory}

Allegory is narrative or description that has meaning beneath the surface one. Allegory is description that has another meaning. The meaning beneath is different from its description. Keraf (2009, p. 140) declared that "allegory is a short story which contains figurative language". Here is an example below. Example: He threw a pine cones at a jovial squirrel and he ran with chattering fear. The example is allegory because the meaning in the sentence is definitely different from its description. Based on the context, the sentence means a man does not feel guilty as leaving his regiment to get his own salvation. He thinks that his act is wise and true things. More over, as he sees a squirrel save itself, he thinks that everything in nature operates upon the principle of selfpreservation.

\subsubsection{Personification}

Personification is a part of figurative language that is giving the attribute of human beings to animal, an object or a concept. It is sub type of metaphor, an implied comparison in which the figurative term of the comparison is always human being. Keraf (2009, p. 140) declared that "personification is a kind of figurative language which describes lifeless thing as if has human being nature". The example: How poor are words in conveying the heights of splendor.

The example above can be said as a personification because in the real context the word Conveying always refers to the human action which is used anatomy such Mouth to speak an utterance to somebody. But by looking the data above that it is used a personification because the word poor words as if a human being which has a nature such able to describe a human action in conveying something. But it is totally a thing which can be a human being as called personification.

\subsubsection{Allusion}

Allusion is a part of figurative language which likes a hint to try suggesting the similarity between people, places, and events. Basically, it is a reference which explicit and implicit to the events, figures, or places in real life (Keraf, 2009, p. 141). Here are the examples of allusion. Some examples are: (7) Bandung is Paris Java; (8) Kartini is also took a part to struggle her similar rights.

In the examples above can be said as allusion because Bandung is a name of city which has a hint to show Paris Java. Kartini is

\footnotetext{
*Author(s) Correspondence:

E-mail: rianahutauruk@yahoo.com
} 
a name of a figure from a strong woman to struggle her rights and for the others woman rights.

\subsubsection{Eponym}

Eponym is a part of figurative language which likes a name of people always connected with specific nature, so the names is used for declaring its nature. Include: Hercules, Spiderman and etc (Keraf, 2009:141). Here are the examples: Adinda (used to say beautiful and gentle woman); Darling (used to say Boy or girlfriend).

The examples above can be identified as eponym because it uses a name of people which always connected with nature. In the real context the word Adinda related to the girl specific nature that has beautiful face and soft feeling, mind to behave with somebody. In other side, Darling is to describe a name for a boy or girlfriend that someone's love very much.

\subsubsection{Epithet}

Epithet is a part of figurative language which likes a hint to declare a specific nature or characteristic of the people or things. That explanation is a descriptive phrase which explains or replaces the name of person or things (Keraf, 2009, p. 141). Here is the example of allusion: Bali is used to say (world heaven); Puteri malam is used for moon.

The examples can be identified as epithet because it uses a name of places which always connected with nature. Which is as a hint to describe its place from its nature, by saying world heaven in tourism spot in Indonesia people can be guessed easily it is BALI. And also Puteri Malam can be known easily by people to declare from its nature is Moon.

\subsubsection{Synecdoche}

Synecdoche is the uses of the part for the whole divides synecdoche into two parts: they are Pars pro toto and Totem proparte. Pars pro toto is a part for the whole and Totem proparte is when the whole things stand for its part (Keraf, 2009, p. 142). Here are the examples: Till evening, I haven't seen his nose
(Pars pro toto (partial represent whole)). The example can be identified as synecdoche (Pars pro toto) because it is as a hint to describe his nose in the sentence which is meant whole of body that consists of head, neck, stomach, hands, feet, etc. It isn't just nose as, because it represents person as whole.

The example of Totem pro parte (whole represent partial): Indonesia got gold medals in the championship. The example above it can be identified as synecdoche (Totem pro parte) because it as a hint to describe Indonesia in the sentence. Which is meant some persons who become winner in a competition and it is not all population in Indonesia take a part in that competition.

\subsubsection{Metonym}

Metonymy is the use of something closely related to the thing actually meant. It can be considered that metonymy is the substitution of a word naming an object for another word closely. Keraf (2009, p. 142) declared that "Metonym is a figurative Language which used a word to declare other things, because it has relationship closely". Here is the example: He is addicted to the bottle.

The example above can be identified as metonym because it is as a hint to describe addicted to the bottle has function to show object bottle has a closely to word addicted. It is another way of saying that he drinks too much whiskey, so it is called using metonymy.

\subsubsection{Antonomasia}

Antonomasia is also a specific form of synecdoche which is formed as using epithets for replacing names, official, profession and so on (Keraf, 2009:142). Here are the examples: My sweet little darling!; Prince, I presented the beautiful jacket only for you.

The examples above can be identified as Antonomasia because the word Darling and Prince always refers to the human who formed as using an Epithet for replacing names and profession. But by looking the data above that he or she hope that his or her boy or girlfriend called him or herself not use his real name but called himself Prince.

\footnotetext{
*Author(s) Correspondence:

E-mail: rianahutauruk@yahoo.com
} 


\subsubsection{Hipflask or Hipalase}

Hipflask or Hipalase is a kind of figurative language where a specific word used to explain that word, which should be affected with another word (Keraf, 2009, p. 142). Here is the example: He is lying on a worry pillow. The example is Hipflask or Hipalase which is worry that affected by the word pillow. Basically 'worry' is human being, not pillow. And the word worry is not suitable combined with pillow. Worry is suitable affected by man. It can be combined such as worry man.

\subsubsection{Irony}

Irony is the opposite of what one means. Irony is a hint that wants to say something with other meaning on what it contains in the words (Keraf, 2009, p. 142). Here are the examples: I know you're a beautiful girl in this world that able to have this position; Not to worry of your capability anymore that you are the people who are able to finish this task in a day well.

The examples above can be identified as Irony because the both sentences are said in other meaning on what it contains of the words in reality I know you're a beautiful girl in this world that able to have this position, Not to worry of your capability anymore that you are the people who are able to finish this task in a day well is always refers to say something true for the human when the position is owned with suitable performances.

\subsubsection{Satire}

Satire is an expression which rejects someone or something. This formed is not needed should have irony nature. Satire contains a critic about the weakness of human being. It main purpose is there will be improvement esthetically (Keraf, 2009, p. 142). Here are the examples: Your voice isn't suitable to be a winner; Your capacity is not able to do this task.

The examples above can be identified as Satire which has almost same nature with Irony because the both sentences are said in other meaning to reject and critic to the other persons Your voice isn't suitable to be a winner, Your capacity is not able to do this task is always refers to say critic and rejection for the human when the position is owned with not suitable performances.

\subsubsection{Innuendo}

Innuendo is like betray with decrease or smaller someone. It declared a critic with indirect suggestion, and often seem not to hurt heart if we see clearly (Keraf, 2009, p. 142) Here are the examples: When the parties always be held, his face often seen clearly; You become a rich man because you did a bit an official commercial.

The examples are Innuendo which is to clarify a critic with indirect suggestion but not to hurt people heart. When the parties always be held, his face often seen clearly from this statement it is to critic someone who always come in all parties be held, he or she comes to party is invited or uninvited by the owner of party. You become a rich man because you did a bit an official commercial from the statement it's like to betray someone who gets a position without knowing clearly status.

\subsubsection{Antiphrasis}

Antiphrasis is like irony which formed of using a word with contrary meaning, which is able regarded as irony or the words used for denying a criminal, bad spirit and etc (Keraf, 2009:142). Here are the examples: Look! A giant has already come; You are an honorable and respected man for waiting longer in this meeting.

The examples above can be identified as Antiphrasis which has same nature with Irony because the both sentences are said in contrary meaning in its contain which is to deny and criminal or bad spirit to the other persons Look! A giant has already come; you are an honorable and respected man for waiting longer in this meeting. Giant is always refers to say Thin or smallest people" in reality but used the word Giant is to deny the criminal and it rejects for the human when the position is owned with not suitable performances to be honorable and respected man.

\footnotetext{
*Author(s) Correspondence:

E-mail: rianahutauruk@yahoo.com
} 


\subsubsection{Pun or Paronomasia}

Pun is a kind of figurative language which uses similar sounds. It is a playing word based on the similarity of its sounds but it has much differential in a meaning (Keraf, 2009, p. 142). Here are the examples: I can find can in the canner; I am able to see a sea that there is a sheep in the ship since departure came and it seen in the seashore.

The examples above are Pun or Paronomasia which uses similar sounds but it has totally different meaning such as Can and Can has different meaning. It can be translated into two parts namely: Dapat or Bisa and Kaleng. It is also different meaning in two words See and Sea. See can be translated Melihat, Sea is Laut and etc.

\section{METHODOLOGY OF THE RESEARCH}

\subsection{The Design of the Research}

The writer uses a qualitative research; the writer concentrates with the process and the result. Creswell $(2009$, p. 4) declared that "qualitative research is means for exploring and understanding the meaning individuals or groups ascribe a social or human problem". By means of it, it gives closer attention to the interpretive nature of inquiry and situating the study within the participants, and the readers of a study. In other side, it is also supported by Arikunto $(2010$, p. 22) that "the data's source of qualitative research is the view which is formed of words spoken and written observed by the researchers, and also the objects were observed by the detail in order to be taken the meaning implied in the document or objects". Therefore, the writer also uses qualitative research for this research design by looking the existences of the participants, situating the study and so on.

\subsection{Subject of the Research}

The subjects of this research are the students at semester $\mathrm{V}$ in FKIP Universitas HKBP Nommensen. The number of classes at semester III are three classes The writer uses three classes of Introduction to Literature (Group A, B, and C).

\subsection{Object of the Research}

The object of the research is focused on the students' handwriting in writing poetry.

\subsection{Data Collection Procedures}

The technique that used in this research has aim to prepare the data that related to the subject of the research exactly the students at FKIP Nommensen Pematangsiantar which consists of 100 students. The data were collected by using the following steps, they are:

(1) Doing observation

(2) Asking the students to write poetry

(3) Collecting their poetry

\subsection{Data Analysis Procedures}

After collecting the data, the writer analyzes data by using the theory of Keraf (2009, pp. 138-145). The data analysis is the process of systematically searching of figurative language produced on the students' poetry and figuring out the kinds of figurative language dominantly used by the students in their writing about poetry. In figuring out the kinds of figurative language dominantly used by the students in their writing about poetry, the writer applies the formula. The writer applies some steps in analyzing the data; the steps are:

(1) Reading the students' handwriting of poetry

(2) Coloring the figurative language used by the students in their writing about poetry

(3) Identifying each of figurative language used

(4) Interpreting the meaning of all the figurative languages used

(5) Figuring out the kinds of figurative language dominantly used in their writing about poetry.

\footnotetext{
*Author(s) Correspondence:

E-mail: rianahutauruk@yahoo.com
} 


\section{FINDINGS AND DISCUSSION}

\subsection{Findings}

Based on the background above, the writer found the types of figurative language used on the students' poetry semester $\mathrm{V}$ at FKIP Universitas HKBP Nommensen:

1. Figurative language is metaphor and symbol. Metaphor clearly compares two objects which is quite similar with simile, except the using of "like" or "as". The main purpose of metaphor is to describe an entity, event or quality more comprehensively and concisely and in a more complex way than is possible by using literal language. Whilst the students' answer is "to compare to things without using 'like' or 'as' ", which is one of the characteristic of metaphor. Symbol has a function to express the poet's feelings and thoughts about phenomena, life and death.

2. The type of figurative language is personification. The function is to add life and vividness to expressions or concepts as we always look at the world from the perspective of a human being. In this type of figurative language, many students get the answer right. For example, the student's answer is 'the function of personification is to give human traits to object or ideas. So the words can be more life". This shows that students' understanding on the function of personification is fairly good.

\subsection{Discussion}

This research has formulated some suggestions that need to be done for the further improvement in the study of literature. First, it is important for the lecturer to give more attention in teaching the theory of figurative language. The results of this study show that the students need more hours to learn about figurative language including the defintions, the functions, and the identification practice. Second, for further study, it is suggested to find out the students' difficulties in recognizing certain type of figurative language and the reason why such type of figurative language is difficult for them. In addition, it is recommended to make a study on other types of figurative language. Third, for the students, it is important to understand the distinction between figurative languages to appreciate literature by alternative learning thorugh reading poems, songs, or novel which contain figurative language.

\section{CONCLUSION AND SUGGESTION}

\subsection{Conclusion}

In teaching Figurative language, one should remember that the meaning of "figure" is "drawing" or "picture". Figures of speech such as personification and apostrophe create pictures in the mind of the reader or listener. These pictures help convey the message faster and more vividly than words said literally. We use figures of speech to add colour and interest, and to awaken the imagination. Figurative language is everywhere, from classical works like those of Shakespeare or the Bible, to everyday speech, pop music, television and commercial issues. It makes the reader or listener use their imagination and understand much more than the simple literal words. Students are mostly concerned with the literal meanings and find in figurative language one of the hardest obstacles. They need to realize that the poets do not use figures of speech as pieces of ornament to decorate their poems, but rather to carry complicated human experiences and "to stand for the thing, idea, feeling, or attitude" they are trying to communicate (Deedari and Mansouri, 2004, p. 12). Students need to know that people do use figures of speech in their everyday speech. These figures should not be studied in isolation, but rather in their relationship to the whole poem. To understand the function of each figure, the teacher has to give simple and concrete examples. In teaching poetry, every teacher needs to call upon a number of techniques and methods. If teachers of poetry disagree on the methods of teaching a certain

\footnotetext{
*Author(s) Correspondence:

E-mail: rianahutauruk@yahoo.com
} 
poet, they must agree on goals: To put their students in touch with the mind of that poet. No doubt, it is known for every one that "good poetry lessons occur in classrooms where young people are guided by responsive teachers who implement as well as they plan" (Brewbaker: 22). The students should know that the difference between 'apostrophe' and 'personification' is that in an apostrophe the person referred to has to be absent, whereas in personification it is not necessarily so. Moreover, in an apostrophe persons are merely referred to, whereas in personification inanimate objects become endowed with human qualities.

\subsection{Suggestion}

Having seen the result of the research, the writer would like to offer some suggestions to be considered as follows: (1) In English poetry's class, the lecturer should explain the theory and application about the poetry to the students. This is very important to get more understanding and knowledge for the students who sit in the class of poetry. (2) Poetry class should be offered two or three semester for the students in order to make them more progrees in the part of writing English poetry. (3) To see the research findings, to other researcher can make a new research about figurative language or they can complete this research in next time to progress education better because there is no practice without theory.

\section{REFERENCES}

Alm-Arvius, C. (2003). Figures of speech. Sweden: Studentlitteratur AB.

Arikunto, S. (2010). Prosedur penelitian: Suatu pendekatan praktik. Jakarta: PT Rineka Cipta.
Arnold, E., \& Von Hollander, E. (2011). Love letters. New York: Plough Publishing House.

Brewbaker, J. (2005). Fifty-five teachers, poems in hand, approach the cruelest month. English Journal, 94(4), 18-22.

Brown, D. (2004). Teaching by principles: An interactive approach to language pedagogy. San Francisco: Pearson Education.

Creswell, J. W. (2009). Research design: Qualitative, quantitative, and mixed methods approaches. (Third Edition). London: Sage Publication, Inc.

Dalman, H. (2012). Keterampilan menulis. Jakarta: PT Raja Grafindo Persada.

Dancygier, B. and Sweetser, E. (2014). Figurative languages. Cambridge: Cambridge University Press.

Deedari, R., \& Mansouri, M. (2004). Understanding poetry. Tehran: Rahnama Publication.

Gluckberg, S. (2001). Understanding figurative language: From metaphors to idiom. Oxford: Oxford University Press.

Harmer, J. (2004). How to teach writing. London: Pearson Education Limited.

Heller, M. (2006). Linguistic minorities and modernity: Second Edition. London: British Library Cataloguing-inPublication Data.

Keraf, G. (2009). Diksi dan gaya bahasa. Jakarta: PT Gramedia Pustaka Utama.

Lazar, G. (2003). Meaning and metaphors. Cambridge: Cambridge University Press.

McDonough, J. and Shaw, C. (1993). Materials and methods in ELT: A teachers' guide. Oxford: Blackwell.

Picken, D. J. (2007). Literature, metaphor and the foreign language learner. New York: Palgrave Macmillan.

Quinn, A. (1982). Figures of speech: 60 ways to turn a phrase. Layton: Gibbs Smith Publisher.

Ratumanan, T. G., \& Laurens, T. (2003). Evaluasi hasil belajar yang relevan dengan kurikulum berbasis kompetensi. Surabaya: Unesa University Press.

*Author(s) Correspondence:

E-mail: rianahutauruk@yahoo.com 
Sayakhan, N. I. (2019). The use of personification and apostrophe as facilitators in teaching poetry. Journal of Language Studies a جوث مجalthat

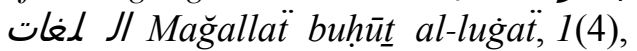
98-106.

*Author(s) Correspondence:

E-mail: rianahutauruk@yahoo.com 